INVITED REVIEW

\title{
The clinical, pathological, and genetic features of familial isolated pituitary adenomas
}

\author{
Albert Beckers and Adrian F Daly \\ Department of Endocrinology, Centre Hospitalier Universitaire de Liège, Domaine Universitaire du Sart Tilman, University of Liège, 4000 Liège, Belgium \\ (Correspondence should be addressed to A Beckers; Email: albert.beckers@chu.ulg.ac.be)
}

\begin{abstract}
Pituitary adenomas occur in a familial setting in multiple endocrine neoplasia type 1 (MEN1) and Carney's complex (CNC), which occur due to mutations in the genes MEN1 and PRKAR1A respectively. Isolated familial somatotropinoma (IFS) is also a well-described clinical syndrome related only to patients with acrogigantism. Pituitary adenomas of all types - not limited to IFS - can occur in a familial setting in the absence of MEN1 and CNC; this phenotype is termed familial isolated pituitary adenomas (FIPA). Over the past 7 years, we have described over 90 FIPA kindreds. In FIPA, both homogeneous and heterogeneous pituitary adenoma phenotypes can occur within families; virtually all FIPA kindreds contain at least one prolactinoma or somatotropinoma. FIPA differs from MEN1 in terms of a lower proportion of prolactinomas and more frequent somatotropinomas in the FIPA cohort. Patients with FIPA are significantly younger at diagnosis and have significantly larger pituitary adenomas than matched sporadic pituitary adenoma counterparts. A minority of FIPA families overall $(15 \%)$ exhibit mutations in the aryl hydrocarbon receptor-interacting protein (AIP) gene; AIP mutations are present in only half of IFS kindreds occurring as part of the FIPA cohort. In families with AIP mutations, pituitary adenomas have a penetrance of over $50 \%$. AIP mutations are extremely rare in patients with sporadic pituitary adenomas. This review deals with pituitary adenomas that occur in a familial setting, describes in detail the clinical, pathological, and genetic features of FIPA, and addresses aspects of the clinical approach to FIPA families with and without AIP mutations.
\end{abstract}

European Journal of Endocrinology 157 371-382

\section{Introduction}

The etiology of pituitary tumors is an issue that provokes continued interest among endocrinologists. This interest stems from the variability in clinical presentation and symptom burden, the unpredictability of tumor growth, and the often complex management. Historically, there has been considerable uncertainty concerning the actual prevalence of pituitary tumors, with a lack of connection between data from autopsy and radiological series and clinical data. Assessments based on unselected populations undergoing autopsy or magnetic resonance imaging (MRI) suggest that pituitary tumors - almost invariably anterior pituitary adenomas - occur very frequently. A meta-analysis suggested a mean pituitary tumor prevalence of 14.4 and $22.5 \%$ in autopsy and radiological series respectively (1). In contrast, the few epidemiological studies performed in the past indicated that pituitary tumors occurred infrequently, with a rate of 190-280 cases/ million (1:3571 to 1:5263 individuals) being reported overall (2). Between these two extremes lies the most practically relevant information, namely the prevalence of clinically apparent pituitary tumors or those tumors that utilize health care resources during their diagnosis, treatment, and follow-up. Recently, we reported some of the first evidence regarding clinically apparent pituitary adenoma prevalence in the modern era. This newer epidemiological evidence suggests that pituitary adenomas occur relatively frequently in the general population, with an overall rate of one case in 1064 of the population (3). These results indicate that clinically apparent pituitary adenomas are more than three times more common than previously thought, which in turn increases the need to understand the pathophysiological mechanisms that give rise to these tumors.

A wealth of studies have been conducted on the molecular genetics of pituitary adenomas in an effort to determine their pathophysiology. Mutations in a series of genes, some relatively frequent and some rare, have been described and characterized in the experimental setting. Chief among these is the gsp gene that encodes the $\alpha$-subunit of the Gs, a heterotrimeric G-protein. Activating mutations in gsp lead to constitutive activation of Gs $\alpha$, increased adenylyl cyclase activity and overproduction of cAMP. Up to $40 \%$ of somatotropinomas have mutations in gsp (4). Other genetic abnormalities associated with pituitary tumorigenesis or abnormal proliferative characteristics are listed in Table 1. 
While many genetic abnormalities have been described in the setting of pituitary adenomas, few are involved in familial or inherited conditions. Familial pituitary tumors account for $\sim 3 \%$ of pituitary adenomas (5). Multiple endocrine neoplasia type 1 (MEN1) and Carney's complex (CNC) are well-characterized inheritable syndromes that are associated with, among other features, pituitary adenomas. Isolated familial somatotropinomas (IFS) have been recognized as occurring in a familial setting for some time and the genetic pathophysiology has been the subject of intense interest. Over the last 7 years, a newer clinical condition, termed familial isolated pituitary adenomas (FIPA), has emerged, which encompasses a wider spectrum of pituitary adenomas occurring in a familial setting than only somatotropinomas. This review addresses the features of pituitary disease occurring in the familial setting with particular attention on recent information concerning the clinical, pathological, and genetic features of FIPA.

\section{Familial causes of pituitary adenomas}

\section{MEN1}

MEN1 syndrome, an autosomal dominant disease caused by mutations in the MEN1 gene on chromosome $11 \mathrm{q} 13$ that encodes the regulatory protein menin, is characterized by the presence of typical patterns of endocrine active and inactive tumors and non-endocrine tumors (6). In patients with mutations in the MEN1 gene, pituitary adenomas occur in $\sim 40 \%$ of cases (7). These data are supported by murine models of men1 gene knockout, in which 37\% of heterozygotic animals had pituitary tumors in adulthood (8). While no genotype-phenotype relation has been shown among the hundreds of MEN1 mutations now described, in familial MEN1, pituitary disease is significantly more frequent than in sporadic MEN1 cases (9). Prolactinomas predominate in MEN1, are larger than their sporadic counterparts and have a poorer response to dopamine agonist therapy (7). In MEN1, pituitary tumors are twice likely to be macroadenomas than in cases of sporadic pituitary adenomas ( $85 \%$ vs $42 \%$ respectively). In keeping with this, tumor signs caused by local compression are more frequent in MEN1 than in sporadic pituitary tumors. Females with MEN1 have an increased risk of developing a pituitary tumor and acromegaly demonstrates a female preponderance in the setting of MEN1 (7). Despite the in-depth characterization of MEN1 clinically and genetically, more than $20 \%$ of cases with clinical features characteristic of MEN1 have no demonstrable genetic mutation, raising the possibility of the involvement of other genes in this syndrome. Recently, a mutation in the CDKN1B gene, which codes for the cyclin-dependent kinase inhibitor $\mathrm{p} 27^{\mathrm{Kip} 1}$, was shown to lead to a MEN1-like syndrome in a rat model and a human kindred (10). In the human setting, a germline nonsense mutation in the CDKN1B gene on chromosome 12 was associated with acromegaly, primary hyperparathyroidism, renal angiomyolipoma, and testicular cancer among various members of the kindred. A second patient with a MEN1-like phenotype and no MEN1 mutation was recently identified as having a CDKN1B gene mutation (11). The female patient had a small-cell neuroendocrine cervical carcinoma (in which loss of heterozygosity $(\mathrm{LOH})$ for CDKN1B and lack of $\mathrm{p} 27$ protein staining were found), Cushing's disease, and hyperparathyroidism. No relevant family history of MEN1-like features was seen and limited family screening (one brother) was negative. Despite the MEN1-like features of the patients described, studies from Ozawa and colleagues at the NIH and from

Table 1 Genetic mutations or alterations occurring in the setting of pituitary adenomas.

\begin{tabular}{ll}
\hline Gene & Defect \\
\hline Cyclin D1 & Overexpression in non-secreting adenomas and somatotropinomas \\
Gsp & Somatic activating mutations in up to $40 \%$ of somatotropinomas \\
& Mosaicism in McCune-Albright syndrome (somatotropinoma, somatomammotropinoma, and Cushing's \\
syndrome in association with precocious puberty, hyperthyroidism, and dermal and bony lesions) & Truncation mutations in Carney's complex leading to somatolactotrope hyperplasia and adenomas \\
PRKAR1 & Alternative transcription initiation in pituitary adenomas \\
Pdt-FGFR4 & Increased expression in more aggressive pituitary tumors \\
PTTG & Diminished expression in prolactinoma \\
BMP-4 & Promoter methylation in non-secreting adenomas, prolactinomas, and somatotropinomas \\
GADD45G & Promoter methylation in non-secreting adenomas and gonadotropinomas \\
MEG3a & Inactivating mutations in all pituitary adenoma types \\
MEN1 & Point mutations in invasive pituitary adenomas \\
PKC & Promoter methylation in pituitary adenomas \\
p16 & Germline heterozygous nonsense mutation in MENX, a novel, rare MEN1-like syndrome \\
CDKN1B (p27Kip1) & Promoter methylation in pituitary adenomas \\
Retinoblastoma & Promoter methylation in non-functioning adenomas \\
ZAC & Germline mutations and loss of heterozygosity in 15\% of FIPA cases. Seen in familial/sporadic \\
AIP & somatotropinomas, somatolactotrope adenomas, prolactinomas, non-secreting adenomas, and \\
& Cushing's disease (sporadic only) \\
\hline
\end{tabular}


Georgitsi et al. indicate that CDKN1B mutations appear to account for only a minority of patients with a MEN1 phenotype in the absence of MEN1 gene mutations $(11,12)$

\section{CNC}

$\mathrm{CNC}$ is a rare predominantly familial condition characterized by lentigines, myxomas, Schwann cell tumors, adrenal hyperplasia, and pituitary abnormalities $(13,14)$. CNC is associated with mutations in the protein kinase A $\mathrm{I} \alpha$ regulatory subunit gene (PRKAR1A) in $60 \%$ of cases (15). Pituitary disease in $\mathrm{CNC}$ is characterized by frequent (up to $75 \%$ of cases) hypersecretion of prolactin, growth hormone $(\mathrm{GH})$, and insulin-like growth factor-I (IGF-I), which can lead to acromegaly in occasional cases. Acromegaly in $\mathrm{CNC}$ is not particularly aggressive, with a mean age at diagnosis of 35.8 years in the largest series from Stratakis's group at the National Institutes of Health in the United States (16). One particular feature of pituitary tumors in $\mathrm{CNC}$ is the presence of somatomammotropic cell multifocal hyperplasia that occurs against a background of normal pituitary and may give rise to adenomas (17). Interestingly, murine models of CNC with prkar 1a knockout, while mirroring many of the tumor abnormalities seen in humans, do not develop marked pituitary disease.

\section{Isolated familial somatotropinomas}

IFS, defined as $\geq 2$ cases of acromegaly or gigantism in a family in the absence of MEN1 or CNC, has long been recognized as a clinical entity. If members of the FIPA cohort are included, more than 50 IFS families including over 120 individuals have now been described in the literature (18-20). IFS is characterized by a slight male predominance and a much younger age at onset (25 years) when compared with sporadic acromegaly, with gigantism being a characteristic feature of IFS kindreds. Tumors in patients with IFS are almost invariably macroadenomas. Before the identification of aryl hydrocarbon receptor-interacting protein (AIP) gene mutations as a potential culprit in some cases of non-MEN1, non-CNC familial pituitary tumorigenesis (21), genetic linkage in IFS to a defined region of chromosome $11 \mathrm{q} 13$ was well demonstrated by the collaborative efforts of Frohman, Teh, Gadelha, and others $(19,22,23)$. Indeed, by 2004, Luccio-Camelo et al. had narrowed the linkage to between microsatellite markers D11S956 and D11S527 on chromosome 11q13.1-q13.3 (24). Despite the advent of mutations in AIP as potential causative features in IFS, the genetic pathophysiology of IFS remains to be fully described as we have found that in $50 \%$ of IFS families, no AIP mutations exist (25).

\section{FIPA}

\section{Background}

In the late 1990s, we became interested in the issue of pituitary adenomas that occurred in a familial setting but were not related to MEN1 or CNC (19). As noted above, IFS had been clearly identified as a clinical entity (19). Little or no evidence of familial links in the setting of other pituitary tumor phenotypes had been published and apart from a handful of case reports on familial prolactinoma $(26,27)$, Cushing's disease (28), and nonsecreting (NS) adenomas (29), there had been no organized effort to study the clinical and genetic characteristics of other pituitary tumors occurring in a familial setting. At our own center, we began to collect and classify kindreds with two or more pituitary adenomas of any type that were unrelated to MEN1 or $\mathrm{CNC}$, a clinical condition that we termed FIPA. In our initial single-center study in 2000, we identified 27 patients who came from FIPA families, which constituted $\sim 1 \%$ of our total pituitary adenoma patient population (30). At that early stage, we noted that patients within the same family could exhibit either the same pituitary tumor type or different tumor types; these were classified as homogeneous and heterogeneous FIPA kindreds respectively. In order to expand the cohort, we began a multicenter collaborative study among tertiary referral centers in France, Italy, and the United States. By 2002, this collaboration had led to the identification and the clinical and genetic characterization of 80 patients among FIPA cohorts (31). Further expansion to 22 centers in France, Italy, and The Netherlands permitted the identification of 64 FIPA kindreds in 2004 which included $\sim 140$ patients (32). At that time, the study was closed and a full series of clinical, biochemical, radiological, and pathological analyses were performed on the entire group. Since then, FIPA kindreds have continued to be reported and more than 90 families have been identified worldwide by our collaborative group.

As an initial step to delineate the profile of patients with FIPA, we undertook a detailed retrospective study of the most clinically relevant features of these FIPA kindreds, namely their hormonal, radiological, and pathological characteristics (18). At least one affected member of each FIPA kindred underwent MEN1 genetic screening, while negative family history and a normal serum calcium and parathyroid hormone (and normal gastrin, vasoactive intestinal polypeptide, and pancreatic polypeptide levels wherever available) were used to rule out MEN1 clinically in all patients. CNC was ruled out by the sequencing of the PRKAR1A gene in one affected member of each family exhibiting homogeneous $\mathrm{GH}$-secreting tumors; thorough clinical profiling and echocardiography were also performed to exclude other $\mathrm{CNC}$ features, such as cardiac myxomas in patients with acromegaly. In order to assess whether there were 
differences between the FIPA cohort and non-familial pituitary tumor patients, a control group of 288 nonMEN1, non-CNC sporadic pituitary patients, was analyzed. This control series was matched with the FIPA cohort for the year of diagnosis.

We used a combination of biochemical and clinical data to classify pituitary tumors according to their secretory profiles as prolactinomas, somatotropinomas, somatolactotrope tumors, Cushing's disease (adrenocorticotropin-secreting tumors), and thyrotropin (TSH)secreting tumors. Gonadotropinomas and NS tumors were grouped separately. Tumors were assessed using computed tomography (pre-1986) or MRI, and were classified as microadenomas $(\leq 10 \mathrm{~mm})$, macroadenomas $(>10 \mathrm{~mm})$, or giant adenomas $(>40 \mathrm{~mm})$; invasive characteristics (cavernous or sphenoid sinus) were also assessed. Surgical findings were collected and analyzed to add direct visual information about tumor size and invasion; results of immunohistochemistry for pituitary hormones were collected wherever available.

\section{Clinical characteristics}

Among the FIPA cohort, families with two, three, and four affected members are seen $(18,25)$. FIPA is characterized by a predominance of prolactinomas and $\mathrm{GH}$-secreting tumors, which account for about $75 \%$ of the cohort (Fig. 1). There is a female preponderance $(62 \%)$ which may be related to the frequent occurrence of prolactinomas in women within the FIPA cohort. Affected members are mainly close relatives, with $74.6 \%$ demonstrating a first-degree relationship (i.e. sibling or filial relationships). As noted above, it had been evident for some years that the tumor phenotype within individual FIPA kindreds could present homogeneously or heterogeneously. FIPA is divided evenly between homogeneous and heterogeneous kindreds. In heterogeneous FIPA kindreds, all tumor phenotypes can occur, but almost invariably at least one prolactinoma or GH-secreting adenoma is seen per family.

Patients from FIPA kindreds are younger at diagnosis - on average 4 years younger - than patients with sporadic pituitary adenomas. When multi-generational families are assessed separately, patients from the later generations (children and grandchildren) have a significantly younger mean age at diagnosis as compared with their forebears $(29.0$ vs 50.5 years, $P<0.0001)$. It is not known whether this generational effect is related to some form of anticipation at the genetic level, or earlier disease recognition due to increased awareness on the part of parents. Patients from homogeneous FIPA kindreds are significantly younger at diagnosis than their heterogeneous kindred counterparts; this effect is significant following multivariate analysis correcting for tumor type.

Overall, tumors from FIPA patients have size characteristics similar to those of the general sporadic pituitary tumor population. Macroadenomas occur in 63\% of FIPA cases and about two-thirds of sporadic cases, and the rates of suprasellar extension and invasion of surrounding tissues do not differ between FIPA and sporadic pituitary tumors. Tumors from heterogeneous FIPA kindreds are more frequently macroadenomas than in the homogeneous FIPA group $(72 \%$ vs $53 \%$ respectively; $P<0.04$ ). This is due to a predominance of NS tumors in the former group (all macroadenomas) and a high frequency of microprolactinomas among homogeneous FIPA kindreds.

\section{Characteristics by tumor type}

- Prolactinomas comprise about $40 \%$ of tumors that occur in the setting of FIPA and as a whole do not

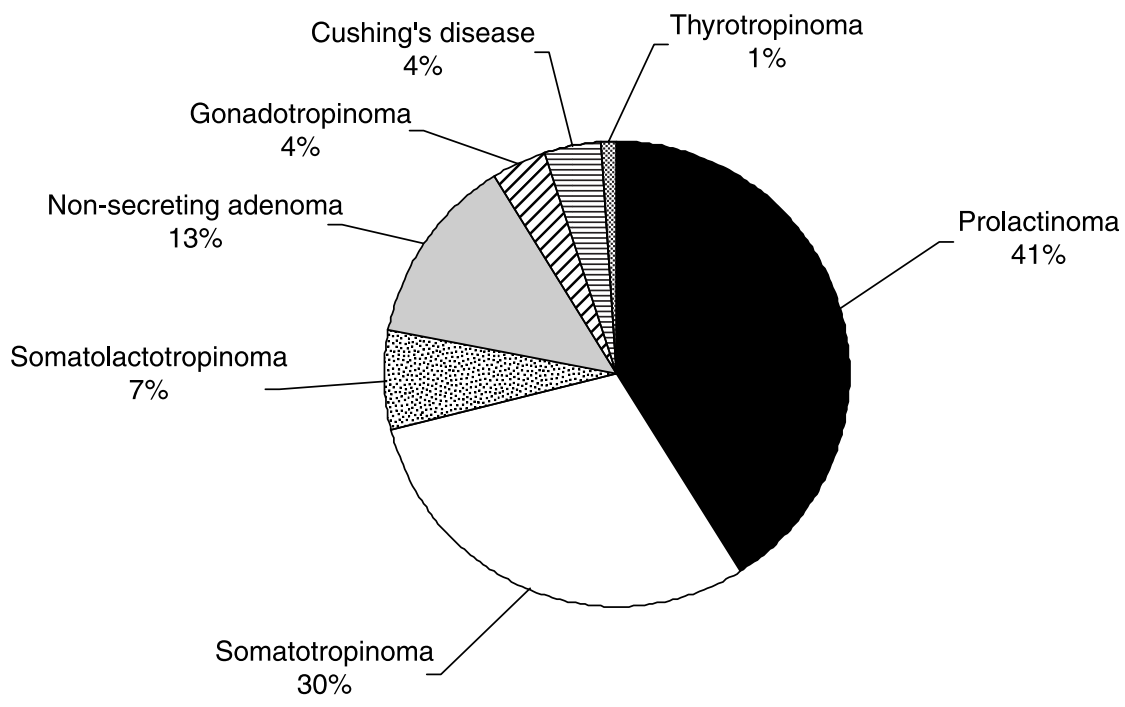

Figure 1 Composition of the FIPA cohort by tumor phenotype. 
differ from sporadic tumors (female predominance, presentation in second to fourth decades of life, microadenomas (33)). All males with prolactinomas in the FIPA cohort had macroadenomas, again in keeping with more aggressive disease in males from the sporadic population. Prolactinomas appear more aggressive when they occur in heterogeneous FIPA kindreds, with suprasellar extension and cavernous sinus invasion being significantly more frequent than in sporadic prolactinomas. Furthermore, the only malignant prolactinoma that occurred at our center was seen in a male from a heterogeneous FIPA family (34).

- Familial somatotropinomas account for 30\% of tumors seen in FIPA. A further 7\% of tumors could be classified as somatolactotropes, although their characteristics are not different from somatotropinomas in the FIPA cohort. Somatotropinomas are equally divided between homogeneous FIPA (essentially IFS) and heterogeneous tumor families. Notably, patients with IFS are diagnosed about 10 years before those with somatotropinomas in heterogeneous FIPA kindreds or in sporadic cases, a finding that echoes previous results on IFS from other groups. Those with IFS within the FIPA cohort are also significantly more likely to exhibit extra- or suprasellar extension of their tumors, with a trend toward more frequent invasion of surrounding structures.

- In FIPA, NS adenomas generally occur in heterogeneous kindreds $(>85 \%)$, are diagnosed significantly earlier $(\sim 8$ years $)$, and are more frequently invasive than their sporadic counterparts.

- Gonadotropinomas, Cushing's disease, and TSHsecreting adenomas are all relatively infrequent in the setting of FIPA (each is $<5 \%$ of the total population). They occur in association with other tumor types in heterogeneous kindreds, although two homogeneous Cushing's disease families and one family with homogeneous gonadotropinoma phenotype were described in the FIPA cohort.

Pituitary tumors in FIPA differ from those seen in the setting of MEN1. FIPA patients with homogeneous acromegaly (i.e. IFS) or Cushing's disease are younger at diagnosis than those with MEN1 (7). Prolactinomas are the most frequent tumors seen in FIPA and MEN1 (as they are in the sporadic setting); however, in MEN1, they account for a much greater proportion of the total $(63 \%)$ when compared with FIPA $(40 \%)$. In FIPA, somatotropinomas are about four times more frequent (34.1\%) when compared with MEN1 $(8.8 \%)$.

\section{Genealogical information}

Among the full FIPA genealogies studied (mean family size 15.4 individuals), pituitary tumors occur in $\sim 14 \%$ of family members. The familiality (degree of relatedness among affected individuals) of FIPA is high at 0.62, suggesting that genetic inheritance is at least partly dominant in character. Maternal transmission is more common among homogeneous than heterogeneous FIPA, potentially due to a high number of motherdaughter homogeneous prolactinoma kindreds (Fig. 2). A paternal transmission pattern is seen predominantly in patients with heterogeneous somatotropinomas, whereas homogeneous somatotropinomas (IFS) was characterized mainly (65\%) by presentation in siblings.

\section{The genetics of FIPA}

By definition, patients with FIPA have mutations in neither the MEN1 nor the PRKAR1A gene. In the clinical studies outlined above, screening for MEN1 mutations was performed in at least one affected member of each kindred, while PRKAR1A screening was performed in relevant kindreds with acromegaly. In IFS kindreds, a series of genetic studies have been undertaken to out-rule the involvement of mutations in candidate genes, some in the region of chromosome 11q13. No mutations in $g s p$, the GH releasing hormone (GHRH)-receptor gene, or the requiem gene were seen in IFS kindreds (35-37).

In an important advance, a study by Vierimaa et al. in May 2006 described a detailed genome-wide screening and DNA mapping study for genes involved in the pathogenesis of pituitary tumors that occurred in a familial setting (21). In these families, combinations of somatotropinomas, mixed GH-prolactin-secreting tumors and prolactinomas were seen. In affected members, the group discovered inactivating mutations in the gene that encodes AIP on chromosome 11q13.3. Analysis of tumor samples from affected individuals noted loss of heterozygosity at the AIP locus, suggesting that tumors were null for AIP. Two mutations were found among a Finnish cohort, Q14X in familial and sporadic pituitary adenoma cases and an IVS3-1G $>$ A mutation in splice acceptor site of exon 4 in one patient with a sporadic pituitary adenoma. In addition, an R304X mutation was described in an Italian sibling pair with acromegaly, while familial pituitary tumor kindreds in Turkey and Germany demonstrated no AIP mutations. Given the phenotypic similarities between families within the FIPA cohort and those reported by Vierimaa et al. (21), a study was performed to assess whether AIP mutations contributed significantly to the pathogenesis of tumors in the setting of FIPA.

In an international cohort from nine countries, 156 patients comprising 73 FIPA families were included and were classified according to the disease definitions used in earlier studies of the clinical characteristics of FIPA $(18,25)$. A total of 11 out of 73 (15.1\%) FIPA families harbored ten different germline AIP mutations, one FIPA family from Italy (unrelated to that reported by Vierimaa et al.) had an R304X mutation, and the 

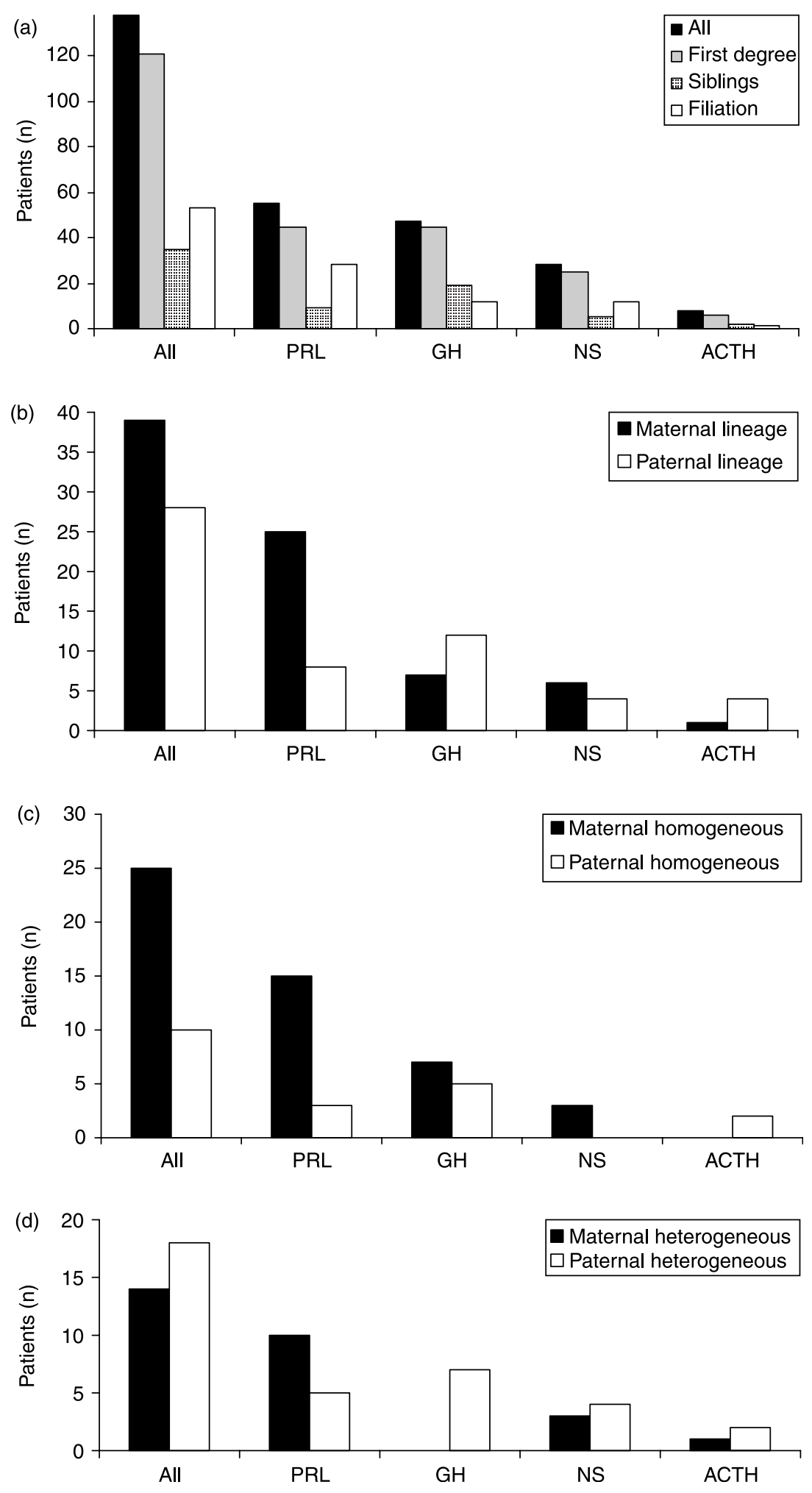

Figure 2 Distribution of first-degree-related affected members from isolated pituitary adenoma families. Affected members are shown by (a) type of relation; (b) potential parental lineage; (c) potential parental lineage in families with homogeneous tumor phenotype expression; and (d) potential parental lineage in families with heterogeneous tumor phenotype expression. rest were novel. Importantly, only $50 \%$ of the FIPA families with homogeneous acromegaly/IFS demonstrated AIP mutations. Indeed, the lack of AIP mutations in FIPA kindreds with apparently strong familiality for pituitary tumors (multiple three-member kindreds and a four-member family) indicates that additional causes are involved in the genetic pathophysiology of FIPA. 
The characteristics of the AIP mutation-bearing FIPA families are outlined in Table 2. The range of patient and tumor characteristics seen in AIP mutation-positive FIPA kindreds is quite variable. FIPA patients with AIP mutations are significantly younger at diagnosis than those without AIP mutations ( $\sim 12$ years), while their maximum tumor diameter is significantly larger in the group with AIP mutations than those without. The majority of FIPA families with AIP mutations have somatotropinomas or mixed $\mathrm{GH}$-prolactin-secreting tumors, but in one FIPA family, a patient with a NS tumor (negative GH and prolactin immunohistochemistry) occurred in association with a prolactinoma in the other affected family member. When immunohistochemical and hormonal secretion patterns in FIPA patients with AIP mutations are considered, a further degree of complexity is added. For instance, patients classified as having 'somatotropinomas' are in fact not a uniform group, with $62 \%$ having elevations in $\mathrm{GH}$ and IGF-I alone, while $38 \%$ also had elevated prolactin. In terms of immunohistochemistry, 'somatotropinoma' patients with AIP mutations can demonstrate staining for $\mathrm{GH}$ alone (59\%), $\mathrm{GH}$ and prolactin (33\%), or $\mathrm{GH}$ and FSH (8\%). Indeed, the same AIP mutation can lead to various clinical phenotypes in different familial kindreds, with a somatotropinoma and a prolactinoma occurring in one family with an R271W mutation, and only acromegaly occurring in another unrelated family with the same mutation. The Q14X mutation seen relatively frequently among familial and sporadic pituitary tumor patients from Finland was not identified within FIPA families. The fact that this mutation was also not identified among larger sporadic and familial pituitary tumor populations in Europe, Japan, and the U.S. suggests that it is due to a founder mutation and is particularly characteristic of pituitary disease in Northern Finland (38-41).

Many AIP mutations have now been demonstrated in the setting of isolated pituitary adenomas, both familial and more rarely sporadic (Fig. 3). The functional implications of these mutations in AIP remain to be determined as relevant studies of protein expression and ligand-receptor interactions relating to these reported AIP mutations are wholly lacking. Experimental data on aspects of the structure of AIP do, however, provide some useful indicators. AIP, a member of the immunophilin family of proteins, is 330 amino acids in length and contains a number of conserved regions. Among these are three tetratricopeptide repeat (TPR) domains and a FK506 binding protein-type peptidyl-prolyl cistrans isomerase (FKBP-PPI) domain; the latter is characteristic of immunophilin proteins. Most information available on the structure-function relationships of AIP relate to the third TPR domain and the carboxy-terminal amino acids (42). The third TPR domain is required for the interaction of AIP with a dimer of heat shock protein 90 (hsp90) and with the aryl hydrocarbon receptor (AhR) (43). Mutations of the AIP third TPR domain in the mouse prevent or decrease interactions with hsp90, AhR, or both $(44,45)$, while removal of the final carboxy-terminal amino acids prevents binding to AhR (46).

Many AIP mutations leading to protein truncations would either prevent AIP being encoded entirely or would remove the vital third TPR domain and the carboxy-terminal. Relatively little is known regarding the function of the amino terminus of AIP; however, its amino acid sequence is highly conserved across species. This suggests that amino acid substitutions, such as $\mathrm{R} 16 \mathrm{H}$ for instance, could be expected to have functional significance. Indeed, since we reported germline R16H changes in a FIPA family, others have noted similar mutations in four sporadic pituitary adenoma patients and also in the germline and tumors of two patients with colorectal carcinoma (and family histories of colorectal, carcinoid, and other tumors) $(47,48)$. A full appreciation of the effect of $\mathrm{R} 16 \mathrm{H}$ on AIP expression and/or function will be required to determine whether this is

Table 2 Characteristics of patients and asymptomatic carriers with AIP mutations in the familial isolated pituitary adenomas cohort.

\begin{tabular}{|c|c|c|c|}
\hline AIP mutation & Relation between members & Disease phenotype & $\begin{array}{l}\text { Mutation-positive asymptomatic } \\
\text { family members }\end{array}$ \\
\hline $\mathrm{R} 16 \mathrm{H}$ & Two first cousins & Acromegaly & 0 \\
\hline G47_R54del & Two siblings & Acromegaly & $\begin{array}{l}2 \text { (mother and sister of affected subjects); } \\
\text { sister with hyperprolactinemia but no tumor }\end{array}$ \\
\hline Q142X & $\begin{array}{l}\text { Three siblings and one daughter of } \\
\text { one affected sibling }\end{array}$ & $\begin{array}{l}\text { Acromegaly/gigantism and } \\
\text { prolactinoma }\end{array}$ & 0 \\
\hline E174fs & Two siblings and a maternal aunt & $\begin{array}{l}\text { Acromegaly/gigantism and } \\
\text { prolactinoma }\end{array}$ & $\begin{array}{l}7 \text { (grandparent, parent, and siblings of } \\
\text { affected subjects) }\end{array}$ \\
\hline Q217X & Two siblings & Acromegaly & 1 (nephew of affected subjects) \\
\hline Q239X & Parent and one offspring & Acromegaly/gigantism & $\begin{array}{l}3 \text { (grandparent, uncle, and sibling of affected } \\
\text { offspring) }\end{array}$ \\
\hline K241E & Two siblings & $\begin{array}{l}\text { Prolactinoma and non-secreting } \\
\text { adenoma }\end{array}$ & 2 (children of affecteds) \\
\hline R271W & Parent and one offspring & Acromegaly & 0 \\
\hline R271W & Parent and one offspring & Acromegaly and prolactinoma & 0 \\
\hline Q285fs & Two siblings & Acromegaly/gigantism & 0 \\
\hline R304X & Two siblings and one nephew & Acromegaly/gigantism & 4 (siblings of affected subjects) \\
\hline
\end{tabular}




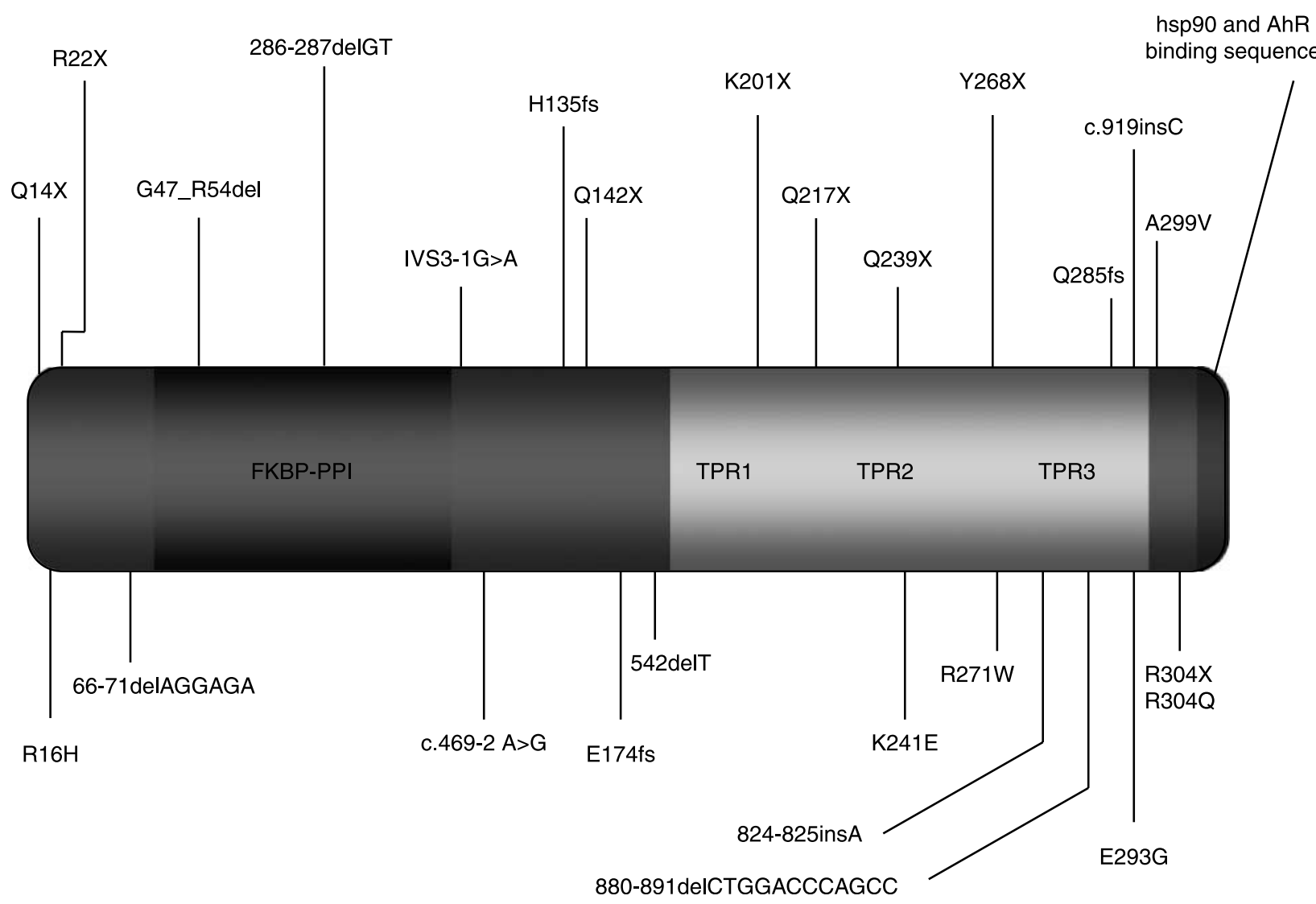

Figure 3 The AIP protein with functional domains highlighted and reported genetic mutations noted. FKBP-PPI, FK506 binding protein-type peptidyl prolyl cis-trans isomerase; TPR, tetratricopeptide repeat domain; hsp90, heat-shock protein 90, AhR, aryl hydrocarbon receptor. Adapted with permission from Daly AF et al. Aryl hydrocarbon receptor-interacting protein gene mutations in familial isolated pituitary adenomas: analysis in 73 families. Journal of Clinical Endocrinology and Metabolism May 2007 92(5) 1891-1896. Copyright 2007, The Endocrine Society. Reference (25).

truly a pathogenic mutation. Other missense mutations involving conserved residues (R271W and K241E) have been identified in FIPA families; the former concerns a highly conserved arginine that forms part of the third TPR domain. Mutation studies of amino acids in this region of AIP in the mouse prevent hsp90/AhR binding. Similarly, K241E is a conserved amino acid, although its functional role is indeterminate at this time.

To date, most studies related to AIP have focused primarily on the modulation of dioxin-related cellular responses via the interaction of AIP with its receptor AhR and an hsp90 dimer. This is clearly an important function, with depletion and augmentation of intracellular AIP concentrations leading to enhanced and decreased ubiquitin-mediated degradation of AhR (49). However, AhR has been shown to have a wide range of effects on cellular signaling cascades, not only those limited to dioxin-mediated responses, e.g. induction of hepatic cytochrome $\mathrm{P} 450$ subtype $1 \mathrm{~A} 1$ expression. AhR shares affinity with hypoxia inducible factor- $1 \alpha$ $($ HIF- $1 \alpha)$ for the aryl hydrocarbon nuclear translocator
(ARNT), through which multiple cellular cascades can be modulated; newer evidence suggests that AhR, HIF$1 \alpha$, and ARNT are involved in a complex crosstalk at a transcriptional level involving multiple response elements and DNA motifs (50). Crosstalk between AhR and other transcription factors has been shown to include nuclear factor- $\kappa \mathrm{B}$, retinoblastoma protein, and estrogen receptor- $\alpha$ (51). Interestingly, it has been suggested that AhR-ARNT can modulate estrogen receptor signaling, potentially explaining the role of dioxin-related toxins as environmental 'endocrine disruptors' (52). Furthermore, AIP appears to play a separate role in the selective modulation of the cAMPspecific phosphodiesterase PDE4A5, with AIP reversibly inhibiting PDE4A5, and can reduce the ability of protein kinase to phosphorylate PDE4A5 (53). Interestingly, a mutation at the arginine at position 271 (a mutation site in two FIPA families) reduced the interaction of AIP with PDE4A5. While the effects of AIP modulation of PDE4A 5 on cell proliferation remain to be determined, a mutation-sensitive effect of AIP on cAMP levels would 
appear to be a relevant line of investigation in determining the role of AIP mutations in pituitary tumorigenesis. Recently, a specific interaction of phosphodiesterase PDE2A with AIP has been reported that serves to inhibit dioxin- and cAMP-related AhR nuclear translocation and gene transcription (54). Given the important role of AIP in modulating AhR levels, inactivating mutations of AIP appear likely to interfere with multiple physiological signaling cascades and xenobiotic responses.

\section{Perspectives}

The occurrence of tumors in a familial setting represents a useful starting point for the investigation of their genetic and molecular tumorigenesis, as evidenced by the study of MEN1 and CNC. Familial pituitary adenomas are a typical feature of these and other newer hereditary neuroendocrine tumor syndromes related to mutations in CDKN1B and AIP. However, despite molecular genetic advances, the clinical recognition and practical management remain the initial step and final goal in dealing with novel familial endocrine syndromes.

As described above, FIPA encompasses a wider phenotypic definition of familial pituitary tumors than permitted by the established condition of IFS, and virtually all combinations of pituitary tumors can occur in homogeneous and heterogeneous patterns within families. Thus, families exhibiting isolated somatotropinomas and prolactinomas can be readily described using the term FIPA. Furthermore, FIPA can be used to describe such kindreds in the presence or absence of AIP mutations, whereas the alternate description of pituitary adenoma predisposition is limited to the minority of families with a confirmed AIP mutation.

Some years ago, we chose the term FIPA for the description of our cohort for a number of reasons. First, it is broad yet clinically descriptive, as befits a label for an investigative condition of often uncertain molecular etiology. With the advent of AIP mutations as a causative agent for familial pituitary adenomas, we believe that FIPA remains valid as a terminology particularly given that only $15 \%$ of FIPA cases are linked to AIP mutations. Furthermore, as AIP is thought to be a culprit in only $50 \%$ of IFS cases, IFS also remains a disease classification with clear clinical utility. Secondly, FIPA readily follows a naming format similar to that used in other forms of hereditary hormone excess and endocrine cancers occurring in single organs, such as familial isolated hyperparathyroidism (FIHP) or familial isolated medullary thyroid carcinoma (FMTC) (55). Both of these conditions, like FIPA, are described in terms of their clinical and familial nature (56), but can be caused by various identified genetic mutations (e.g. MEN1 and HRPT2 for FIHP (57-60), while linkage to other genes and chromosomal regions has been suggested in cases without a defined genetic pathophysiology $(61,62)$. Similarly, FIPA permits the accurate clinical description of isolated pituitary tumors occurring in families while allowing for multiple genetic causes, such as AIP, and others yet to be described.

Currently, the FIPA cohort, including those with AIP mutations, remains free of other discrete endocrine and non-endocrine conditions that would suggest a characteristic clinical syndrome. However, it cannot be discounted that germline AIP mutations could be associated with a predisposition to tumors other than pituitary adenomas particularly as missense AIP mutations have been noted in the setting of colonic adenoma tissue. While other highly prevalent tumors, such as thyroid adenomas, are present in certain FIPA patients, demonstration of LOH for AIP or abnormal AIP protein expression would be required before expanding the clinical phenotype beyond pituitary adenomas. These questions will be answered in part by the clinical phenotype exhibited by aip knockout mouse models now at an advanced stage of development. However, there is an important caveat in extrapolating murine data on AIP function to humans because the interactions of AIP with AhR in the mouse differ from that in the human in terms of AIP-cytoplasmic localization and AIP-induced shuttling to the nucleus $(63,64)$. It may be that this inter-species divergent AIP/AhR function may lead to different disease risks and tumor expression in humans when compared with mice.

With the identification of AIP mutations as being involved in the etiology of familial pituitary tumors, the issue of screening has been raised (47). In particular, it has been suggested that immunohistochemistry for AIP in pituitary tumor tissue be used to screen operated patients for mutations. While it is indeed feasible to undertake AIP immunohistochemistry, further information will be required on a number of fronts. Initially, the presence or absence of AIP in pituitary tumor samples requires information regarding the patterns of expression of AIP in the nucleus and cytoplasm of normal pituitary cells. Also, it remains to be determined as to whether various normal pituitary cells (somatotropes, lactotropes, or corticotropes) themselves have distinctive levels of AIP expression. Pituitary adenomas associated with AIP mutations in FIPA and the sporadic setting are heterogeneous in terms of hormonal immunohistochemistry and clinical phenotype and include all types except for thyrotropinomas. Again, the range of AIP expression patterns in these adenomatous cells when compared with normal tissue remains to be determined before immunohistochemical screening can permit identification of AIPmutated specimens. The effects of common first-line and adjunctive treatments (somatostatin analogs, dopamine agonists, and radiotherapy) on AIP expression patterns in somatotropinomas, prolactinomas, and NS tumors have not been studied to date and could theoretically alter immunohistochemical results. AIP immunohistochemistry has, to date, focused on samples derived from 
patients with early truncating mutations of AIP (e.g. the Finnish founder mutation, Q14X). Such mutations would be expected to lead to an absence of AIP protein and a negative immunostain. Mutations that lead to the disruption of crucial amino acids in the third TPR (R271W) or the carboxy-terminal amino acids (R304X) may abrogate or decrease biological AIP function without decreasing protein expression; this could lead to tumor samples containing mutated AIP protein appearing normal on immunohistochemistry. Finally, AIP immunohistochemistry has been based on murine polyclonal antibodies that have unknown cross-reactivity patterns with human immunophilins. For fundamental immunohistochemistry studies on AIP expression in normal and adenomatous pituitary tissues, it would be preferable that monoclonal antibodies directed against known epitopes on the human AIP protein should be used.

Widespread genetic screening for AIP mutations in patients with sporadic pituitary adenomas and in relatives of those bearing AIP mutations requires careful consideration. First, there is considerable divergence in the reported penetrance of pituitary adenomas among kindreds with AIP mutations. In the original report regarding AIP mutations in familial pituitary adenomas, it was suggested that this was a low penetrance disease (21). However, that study was based on a relatively small number of families (three families with two distinct AIP mutations) and limited clinical screening of the kindred. In contrast, we suggest that the penetrance of pituitary disease in AIP mutation-bearing FIPA kindreds is high. Our preliminary data would suggest that well in excess of $50 \%$ of individuals from families with AIP mutations have pituitary adenomas, data that are supported by other groups (65) and are in keeping with the strong reported familiality of FIPA (18). Before widespread genetic screening for AIP mutations among pituitary adenoma patients can be contemplated, the issue of true penetrance will need to be addressed in order to provide informative counseling to patients and to address the vital ethical issues relevant to the study of familial neuroendocrine tumor syndromes (for review see Sukarai et al. (66)). We agree with Melmed that the widespread use of genetic and radiological screening in unselected patients with sporadic pituitary adenomas is not warranted at this time (67). However, given the characteristics of patients with AIP mutations (young age at diagnosis, large tumor size), screening of young patients with aggressive pituitary tumors for AIP mutations should be considered. In the case of relatives of patients with AIP mutation-related pituitary adenomas, AIP screening is recommended.

Patients with pituitary tumors and AIP mutations may have a poorer response to therapy, like many young patients with larger pituitary tumors (68), although this issue has not been studied per se. From a clinical perspective, it may be practical to bear in mind the main characteristics of patients from FIPA kindreds: (1) pituitary adenomas of all types can occur in a familial setting; (2) pituitary tumors in FIPA are larger and diagnosed earlier than sporadic adenomas; (3) 15\% of FIPA and $50 \%$ of IFS families are linked to mutations in AIP; and (4) in the absence of a close family history of pituitary adenomas, AIP mutations are rare. Whatever the genetic pathophysiology is, good endocrine practice involving a detailed family history, standard comprehensive testing of pituitary axes, and pituitary MRI should be applied to all patients with pituitary adenomas. In the case of young patients with aggressive tumors, germline AIP genetic study may be useful (69) and is warranted in the presence of a family history of pituitary tumors without an identified genetic pathophysiology.

\section{Acknowledgements}

The authors would like to acknowledge the invaluable contribution of all physicians at the collaborating centers that provided families with pituitary tumors for the studies described in this review $(18,25,39)$.

\section{References}

1 Ezzat S, Asa SL, Couldwell WT, Barr CE, Dodge WE, Vance ML \& McCutcheon IE. The prevalence of pituitary adenomas: a systematic review. Cancer 2004101 613-619.

2 Davis JR, Farrell WE \& Clayton RN. Pituitary tumours. Reproduction 2001121 363-371.

3 Daly AF, Rixhon M, Adam C, Dempegioti A, Tichomirowa MA \& Beckers A. High prevalence of pituitary adenomas: a crosssectional study in the province of Liege, Belgium. Journal of Clinical Endocrinology and Metabolism 200691 4769-4775.

4 Asa SL \& Ezzat S. Genetics and proteomics of pituitary tumors. Endocrine 200528 43-47.

5 Scheithauer BW, Laws ER Jr, Kovacs K, Horvath E, Randall RV \& Carney JA. Pituitary adenomas of the multiple endocrine neoplasia type I syndrome. Seminars in Diagnostic Pathology 19874 205-211.

6 Agarwal SK, Lee Burns A, Sukhodolets KE, Kennedy PA, Obungu VH, Hickman AB, Mullendore ME, Whitten I, Skarulis MC, Simonds WF, Mateo C, Crabtree JS, Scacheri PC, Ji Y, Novotny EA, Garrett-Beal L, Ward JM, Libutti SK, Richard Alexander H, Cerrato A, Parisi MJ, Santa Anna-A S, Oliver B, Chandrasekharappa SC, Collins FS, Spiegel AM \& Marx SJ. Molecular pathology of the MEN1 gene. Annals of the New York Academy of Sciences 20041014 189-198.

7 Vergès B, Boureille F, Goudet P, Murat A, Beckers A, Sassolas G, Cougard P, Chambe B, Montvernay C \& Calender A. Pituitary disease in MEN type 1 (MEN1): data from the France-Belgium MEN1 multicenter study. Journal of Clinical Endocrinology and Metabolism 200287 457-465.

8 Daly AF, Jaffrain-Rea ML \& Beckers A. Clinical and genetic features of familial pituitary adenomas. Hormone and Metabolic Research 200537 347-354.

9 Wautot V, Vercherat C, Lespinasse J, Chambe B, Lenoir GM, Zhang CX, Porchet N, Cordier M, Beroud C \& Calender A. Germline mutation profile of MEN1 in multiple endocrine neoplasia type 1: search for correlation between phenotype and the functional domains of the MEN1 protein. Human Mutation 200220 35-47.

10 Pellegata NS, Quintanilla-Martinez L, Siggelkow H, Samson E, Bink K, Hofler H, Fend F, Graw J \& Atkinson MJ. Germ-line mutations in p27Kip1 cause a multiple endocrine neoplasia syndrome in rats and humans. PNAS $2006 \mathbf{1 0 3} 15558-15563$.

11 Georgitsi M, Raitila A, Karhu A, van der Luijt RB, Aalfs CM, Sane T, Vierimaa O, Mäkinen MJ, Tuppurainen K, Paschke R, 
Gimm O, Koch CA, Gündogdu S, Lucassen A, Tischkowitz M, Izatt L, Aylwin S, Bano G, Hodgson S, De Menis E, Launonen V, Vahteristo $\mathrm{P} \&$ Aaltonen LA. Germline CDKN1B/p27kip1 mutation in multiple endocrine neoplasia. Journal of Clinical Endocrinology and Metabolism 2007 (Epub).

12 Ozawa A, Agarwal SK, Mateo CM, Burns AL, Rice TS, Kennedy PA, Quigley CM, Simonds WF, Weinstein LS, Chandrasekharappa SC, Collins FS, Spiegel AM \& Marx SJ. The parathyroid/pituitary variant of multiple endocrine neoplasia type 1 usually has causes other than p27Kip1 mutations. Journal of Clinical Endocrinology and Metabolism 200792 1948-1951.

13 Carney JA, Hruska LS, Beauchamp GD \& Gordon H. Dominant inheritance of the complex of myxomas, spotty pigmentation and endocrine overactivity. Mayo Clinic Proceedings 198561 165-172.

14 Stergiopoulos SG \& Stratakis CA. Human tumors associated with Carney complex and germline PPKAR1A mutations: a protein kinase A disease! FEBS Letters 2003546 59-64.

15 Veugelers M, Wilkes D, Burton K, McDermott DA, Song Y, Goldstein MM, La Perle K, Vaughan CJ, O'Hagan A, Bennett KR, Meyer BJ, Legius E, Karttunen M, Norio R, Kaariainen H, Lavyne M, Neau JP, Richter G, Kirali K, Farnsworth A, Stapleton K, Morelli P, Takanashi Y, Bamforth JS, Eitelberger F, Noszian I, Manfroi W, Powers J, Mochizuki Y, Imai T, Ko GT, Driscoll DA, Goldmuntz E, Edelberg JM, Collins A, Eccles D, Irvine AD, McKnight GS \& Basson CT. Comparative PRKAR1A genotype-phenotype analyses in humans with Carney complex and prkar 1a haploinsufficient mice. PNAS 2004101 14222-14227.

16 Boikos SA \& Stratakis CA. Pituitary pathology in patients with Carney Complex: growth-hormone producing hyperplasia or tumors and their association with other abnormalities. Pituitary $20069203-209$.

17 Pack SD, Kirschner LS, Pak E, Zhuang Z, Carney JA \& Stratakis CA. Genetic and histological studies of somatomammotropic tumors in patients with the "Complex of spotty skin pigmentation, myxomas, endocrine overactivity and schwannomas' (Carney complex). Journal of Clinical Endocrinology and Metabolism $2000 \mathbf{8 5}$ 3860-3865.

18 Daly AF, Jaffrain-Rea ML, Ciccarelli A, Valdes-Socin H, Rohmer V, Tamburrano G, Borson-Chazot C, Estour B, Ciccarelli E, Brue T, Ferolla P, Emy P, Colao A, De Menis E, Lecomte P, Penfornis F, Delemer B, Bertherat J, Wemeau JL, De Herder W, Archambeaud F, Stevenaert A, Calender A, Murat A, Cavagnini F \& Beckers A. Clinical characterization of familial isolated pituitary adenomas. Journal of Clinical Endocrinology and Metabolism 200691 3316-3323.

19 Verloes A, Stevenaert A, Teh BT, Petrossians P \& Beckers A. Familial acromegaly: case report and review of the literature. Pituitary $19991273-277$.

20 Frohman LA \& Eguchi K. Familial acromegaly. Growth Hormone and IGF Research 200414 S90-S96.

21 Vierimaa O, Georgitsi M, Lehtonen R, Vahteristo P, Kokko A, Raitila A, Tuppurainen K, Ebeling TM, Salmela PI, Paschke R, Gundogdu S, De Menis E, Makinen MJ, Launonen V, Karhu A \& Aaltonen LA. Pituitary adenoma predisposition caused by germline mutations in the AIP gene. Science 2006312 1228-1230.

22 Teh BT, Kytölä S, Farnebo F, Bergman L, Wong FK, Weber G, Hayward N, Larsson C, Skogseid B, Beckers A, Phelan C, Edwards M, Epstein M, Alford F, Hurley D, Grimmond S, Silins G, Walters M, Stewart C, Cardinal J, Khodaei S, Parente $F$, Tranebjaerg L, Jorde R, Menon J, Khir A, Tan TT, Chan SP, Zaini A, Khalid BAK, Sandelin K, Thompson N, Brandi ML, Warth M, Stock J, Leisti J, Cameron D, Shepherd JJ, Öberg K, Nordenskjöld M \& Salmela P. Mutation analysis of the MEN1 gene in multiple endocrine neoplasia type 1 , familial acromegaly and familial isolated hyperparathyroidism. Journal of Clinical Endocrinology and Metabolism $1998 \mathbf{8 3} 2621-2626$.

23 Poncin J, Abs R, Velkeniers B, Bonduelle M, Abramowicz M, Legros JJ, Verloes A, Meurisse M, Van Gaal L, Verellen C, Koulischer L \& Beckers A. Mutation analysis of the MEN1 gene in Belgian patients with multiple endocrine neoplasia type 1 and related diseases. Human Mutation 199913 54-60.
24 Luccio-Camelo DC, Une KN, Ferreira RE, Khoo SK, Nickolov R, Bronstein MD, Vaisman M, Teh BT, Frohman LA, Mendonca BB \& Gadelha MR. A meiotic recombination in a new isolated familial somatotropinoma kindred. European Journal of Endocrinology 2004 $150643-648$

25 Daly AF, Vanbellinghen JF, Khoo SK, Jaffrain-Rea ML, Naves LA, Guitelman MA, Murat A, Emy P, Gimenez-Roqueplo AP, Tamburrano G, Raverot G, Barlier A, De Herder W, Penfornis A, Ciccarelli E, Estour B, Lecomte P, Gatta B, Chabre O, Sabate MI, Bertagna X, Garcia Basavilbaso N, Stalldecker G, Colao A, Ferolla P, Wemeau JL, Caron P, Sadoul JL, Oneto A, Archambeaud F, Calender A, Sinilnikova O, Montanana CF, Cavagnini F, Hana V, Solano A, Delettieres D, Luccio-Camelo DC, Basso A, Rohmer V, Brue T, Bours V, Teh BT \& Beckers A. Aryl hydrocarbon receptorinteracting protein gene mutations in familial isolated pituitary adenomas: analysis in 73 families. Journal of Clinical Endocrinology and Metabolism 200792 1891-1896.

26 Linquette M, Herlant M, Laine E, Fossati P \& Dupont-Lecompte J. Adenome a prolactine chez une jeune fine dont la mere etait porteuse d'un adenome hypophysaire avec amenorrhee-galactorrhee. Annales d'Endocrinologie 199728 773-780.

27 Berezin M \& Karasik A. Familial prolactinoma. Clinical Endocrinology $1995 \mathbf{4 2} 483-486$.

28 Salti IS \& Mufarrij IS. Familial Cushing disease. American Journal of Medical Genetics 1981 8 91-94.

29 Yuasa H, Tokito S, Nakagaki H \& Kitamura K. Familial pituitary adenoma - report of four cases from two unrelated families. Neurologia Medico-Chirurgica 199030 1016-1019.

30 Valdes-Socin H, Poncin J. Stevens V, Stevenaert A \& Beckers A. Adenomes hypophysaires familiaux isoles non lies avec la mutation somatique NEM-1. Suivi de 27 patients. Annales d'Endocrinologie 200061301.

31 Valdes-Scoin H, Jaffrain Rea ML, Tamburrano G, Cavagnini F, Cicarelli E, Colao A, Delemer B, Brue T, Rohmer V, Wemeau JL, Levasseur S, The B, Stevenaert A \& Beckers A. Familial isolated pituitary tumors: clinical and molecular studies in 80 patients. Endocrine Society's 84th Annual Meeting 2002 P3-663 647.

32 Beckers A. Familial isolated pituitary adenomas. The Ninth International Workshop on multiple endocrine neoplasia (MEN2004). Journal of Internal Medicine 2004255 696-730.

33 Ciccarelli A, Daly AF \& Beckers A. The epidemiology of prolactinomas. Pituitary 20058 3-6.

34 Petrossians P, de Herder W, Kwekkeboom D, Lamberigts G, Stevenaert A \& Beckers A. Malignant prolactinoma discovered by D2 receptor imaging. Journal of Clinical Endocrinology and Metabolism 199985 398-401.

35 Ackermann F, Krohn K, Windgassen M, Buchfelder M, Fahlbusch R \& Paschke R. Acromegaly in a family without a mutation in the menin gene. Experimental and Clinical Endocrinology and Diabetes 1999107 93-96.

36 Jorge BH, Agarwal SK, Lando VS, Salvatori R, Barbero RR, Abelin N, Levine MA, Marx SJ \& Toledo SP. Study of the multiple endocrine neoplasia type 1 , growth hormone-releasing hormone receptor, Gs alpha, and Gi2 alpha genes in isolated familial acromegaly. Journal of Clinical Endocrinology and Metabolism 2001 $86542-544$.

37 Khoo SK, Chan S, Pendek R, Jayaram M, Kanthimanti MS, Wong FK, Motorna O, Valdes-Socin H, Frohman L, Jaffrain-Réa ML, Tamburrano G, Beckers A \& Teh B. Clinical and genome-wide linkage studies of a multigenerational family with acromegaly and the exclusion of requiem gene. Endocrine Society's 84th Annual Meeting 2002 P1-680 312.

$38 \mathrm{Yu}$ R, Bonert S, Saporta I, Raffel LJ \& Melmed S. AIP variants in sporadic pituitary adenomas. Journal of Clinical Endocrinology and Metabolism 200691 5126-5129.

39 Barlier A, Vanbellinghen JF, Daly AF, Silvy M, Jaffrain-Rea ML, Trouillas J, Tamagno G, Cazabat L, Bours V, Brue T, Enjalbert A \& Beckers A. Mutations in the aryl hydrocarbon receptor interacting protein gene are not highly prevalent among subjects with sporadic pituitary adenomas. Journal of Clinical Endocrinology and Metabolism 200792 1952-1955. 
40 Iwata T, Yamada S, Mizusawa N, Golam HM, Sano T \& Yoshimoto K. The aryl hydrocarbon receptor-interacting protein gene is rarely mutated in sporadic GH-secreting adenomas. Clinical Endocrinology 200766 499-502.

41 Toledo RA, Lourenco DM Jr, Liberman B, Cunha-Neto MB, Cavalcanti MG, Moyses CB, Toledo SP \& Dahia PL. Germline mutation in the aryl hydrocarbon receptor interacting protein gene in familial somatotropinoma. Journal of Clinical Endocrinology and Metabolism 200792 1934-1937.

42 Carver LA, LaPres JJ, Jain S, Dunham EE \& Bradfield CA. Characterization of the Ah receptor-associated protein, ARA9. Journal of Biochemical Chemistry 1999273 33580-33587.

43 Petrulis JR \& Perdew GH. The role of chaperone proteins in the aryl hydrocarbon receptor core complex. Chemico-Biological Interactions $200214125-40$.

44 Meyer BK, Petrulis JR \& Perdew GH. Aryl hydrocarbon (Ah) receptor levels are selectively modulated by hsp90-associated immunophilin homolog XAP2. Cell Stress and Chaperones 20005 243-254.

45 Bell DR \& Poland A. Binding of aryl hydrocarbon receptor (AhR) to AhR-interacting protein. The role of hsp90. Journal of Biological Chemistry 2000275 36407-36414.

46 Meyer BK \& Perdew GH. Characterization of the AhR-hsp90-XAP2 core complex and the role of the immunophilin-related protein XAP2 in AhR stabilization. Biochemistry 199938 8907-8917.

47 Georgitsi M, Raitila A, Karhu A, Tuppurainen K, Makinen MJ, Vierimaa O, Paschke R, Saeger W, van der Luijt RB, Sane T, Robledo M, De Menis E, Weil RJ, Wasik A, Zielinski G, Lucewicz O, Lubinski J, Launonen V, Vahteristo P \& Aaltonen LA. Molecular diagnosis of pituitary adenoma predisposition caused by aryl hydrocarbon receptor-interacting protein gene mutations. PNAS 2007104 4101-4105.

48 Georgitsi M, Karhu A, Winqvist R, Visakorpi T, Waltering K, Vahteristo P, Launonen V \& Aaltonen LA. Mutation analysis of aryl hydrocarbon receptor interacting protein $(A I P)$ gene in colorectal, breast, and prostate cancers. British Journal of Cancer $200796352-356$.

49 Lees MJ, Peet DJ \& Whitelaw ML. Defining the role for XAP2 in stabilization of the dioxin receptor. Journal of Biological Chemistry $200327835878-35888$.

50 Lee K, Burgoon LD, Lamb L, Dere E, Zacharewski TR, Hogenesch JB \& Lapres JJ. Identification and characterization of genes susceptible to transcriptional cross-talk between the hypoxia and dioxin signaling cascades. Chemical Research in Toxicology $2006191284-1293$.

51 Harper PA, Riddick DS \& Okey AB. Regulating the regulator: factors that control levels and activity of the aryl hydrocarbon receptor. Biochemical Pharmacology 200672 267-279.

52 Ohtake F, Takeyama K, Matsumoto T, Kitagawa H, Yamamoto Y, Nohara K, Tohyama C, Krust A, Mimura J, Chambon P, Yanagisawa J, Fujii-Kuriyama Y \& Kato S. Modulation of oestrogen receptor signalling by association with the activated dioxin receptor. Nature $2003 \mathbf{4 2 3}$ 545-550.

53 Bolger GB, Peden AH, Steele MR, MacKenzie C, McEwan DG, Wallace DA, Huston E, Baillie GS \& Houslay MD. Attenuation of the activity of the cAMP-specific phosphodiesterase PDE4A5 by interaction with the immunophilin XAP2. Journal of Biological Chemistry 2003278 33351-33363.

54 de Oliveira SK, Hoffmeister M, Gambaryan S, Muller-Esterl W, Guimaraes JA \& Smolenski AP. Phosphodiesterase 2A forms a complex with the co-chaperone XAP2 and regulates nuclear translocation of the aryl hydrocarbon receptor. Journal of Biological Chemistry $2007 \mathbf{2 8 2} 13656-13663$.

55 Marx SJ \& Simonds WF. Hereditary hormone excess: genes, molecular pathways, and syndromes. Endocrine Reviews 200526 615-661.

56 Brandi ML, Gagel RF, Angeli A, Bilezikian JP, Beck-Peccoz P, Bordi C, Conte-Devolx B, Falchetti A, Gheri RG, Libroia A, Lips CJ, Lombardi G, Mannelli M, Pacini F, Ponder BA, Raue F, Skogseid B, Tamburrano G, Thakker RV, Thompson NW,
Tomassetti P, Tonelli F, Wells SA Jr \& Marx SJ. Guidelines for diagnosis and therapy of MEN type 1 and type 2. Journal of Clinical Endocrinology and Metabolism $2001865658-5671$.

57 Wassif WS, Moniz CF, Friedman E, Wong S, Weber G, Nordenskjold M, Peters TJ \& Larsson C. Familial isolated hyperparathyroidism: a distinct genetic entity with an increased risk of parathyroid cancer. Journal of Clinical Endocrinology and Metabolism 199377 1485-1489.

58 Carrasco CA, Gonzalez AA, Carvajal CA, Campusano C, Oestreicher E, Arteaga E, Wohllk N \& Fardella CE. Novel intronic mutation of MEN1 gene causing familial isolated primary hyperparathyroidism. Journal of Clinical Endocrinology and Metabolism $2004894124-4129$.

59 Warner J, Epstein M, Sweet A, Singh D, Burgess J, Stranks S, Hill P, Perry-Keene D, Learoyd D, Robinson B, Birdsey P, Mackenzie E, Teh BT, Prins JB \& Cardinal J. Genetic testing in familial isolated hyperparathyroidism: unexpected results and their implications. Journal of Medical Genetics 200441 155-160.

60 Simonds WF, Robbins CM, Agarwal SK, Hendy GN, Carpten JD \& Marx SJ. Familial isolated hyperparathyroidism is rarely caused by germline mutation in HRPT2, the gene for the hyperparathyroidism-jaw tumor syndrome. Journal of Clinical Endocrinology and Metabolism 200489 96-102.

61 Machens A, Niccoli-Sire P, Hoegel J, Frank-Raue K, van Vroonhoven TJ, Roeher HD, Wahl RA, Lamesch P, Raue F, Conte-Devolx B \& Dralle H. European Multiple Endocrine Neoplasia (EUROMEN) Study Group. Early malignant progression of hereditary medullary thyroid cancer. New England Journal of Medicine $2003 \mathbf{3 4 9} 1517-1525$.

62 Gimm O, Greco A, Hoang-Vu C, Dralle H, Pierotti MA \& Eng C. Mutation analysis reveals novel sequence variants in NTRK1 in sporadic human medullary thyroid carcinoma. Journal of Clinical Endocrinology and Metabolism $1999842784-2787$.

63 Naves LA, Daly AF, Vanbellinghen J-F, Casulari LA, Spilioti C, Magalhâes AV, Azevedo MF, Giacomini LA, Nascimento PP, Mines RO, Rosa JWC, Jaffrain-Rea M-L, Bours V \& Beckers A. Variable pathological and clinical features of a large Brazilian family harboring a mutation in the aryl hydrocarbon receptorinteracting protein gene. European Journal of Endocrinology 2007 157 383-391.

64 Ramadoss P, Petrulis JR, Hollingshead BD, Kusnadi A \& Perdew GH. Divergent roles of hepatitis B virus X-associated protein 2 (XAP2) in human versus mouse Ah receptor complexes. Biochemistry 200443 700-709.

65 Gueorguiev M, Quinton R, Chapple R, Leontiou C, Lolli F, Wass JA, Popovic V, Ribeiro-Oliveira A, Gadelha MR, Clayton RN, Jordan S, Frohman LA, Grossman AB \& Korbonits M. The role of AIP in familial acromegaly. Endocrine Society's 89th Annual Meeting 2007 OR15-2.

66 Sakurai A, Katai M, Hashizume K \& Fukushima Y. Familial neuroendocrine tumor syndromes: from genetics to clinical practice. Pituitary $20069231-236$.

67 Melmed S. Aryl hydrocarbon receptor interacting protein and pituitary tumorigenesis: another interesting protein. Journal of Clinical Endocrinology and Metabolism $2007 \mathbf{9 2}$ 1617-1619.

68 Besser GM, Burman P \& Daly AF. Predictors and rates of treatment-resistant tumor growth in acromegaly. European Journal of Endocrinology 2005153 187-193.

69 Cazabat L, Libe R, Perlemoine K, Rene-Corail F, Burnichon N, Gimenez-Roqueplo AP, Dupasquier-Fediaevsky L, Bertagna X, Clauser E, Chanson P, Bertherat J \& Raffin-Sanson ML. Germline inactivating mutations of the aryl hydrocarbon receptor-interacting protein gene in a large cohort of sporadic acromegaly: mutations are found in a subset of young patients with macroadenomas. European Journal of Endocrinology 2007157 1-8.

Received 24 May 2007

Accepted 18 June 2007 